\title{
The Role of Y-Box Binding Protein 1 in Kidney Injury: Friend or Foe?
}

\author{
Ben Ke Chuqiao Fan Weiping Tu Xiangdong Fang \\ Department of Nephrology, The Second Affiliated Hospital of Nanchang University, Nanchang of \\ Jiangxi, China
}

\section{Key Words}

Y-box-binding protein $1 \cdot$ Acute kidney injury $\bullet$ Chronic kidney disease $\bullet$ Translation

\begin{abstract}
Y-box-binding protein 1 (YB-1) is a multifunctional protein involved in various cellular processes via the transcriptional and translational regulation of target gene expression. YB-1 promotes acute or chronic kidney injury through multiple molecular pathways; however, accumulating evidence suggests that significantly increased YB-1 levels are of great importance in renoprotection. In addition, YB-1 may contribute to obesity-related kidney disease by promoting adipogenesis. Thus, the role of YB-1 in kidney injury is complicated, and no comprehensive review is currently available. In this review, we summarise recent progress in our understanding of the function of YB-1 in kidney injury and provide an overview of the dual role of YB-1 in kidney disease. Moreover, we propose that YB-1 is a potential therapeutic target to restrict kidney disease.

\section{Introduction}

Y-box-binding protein 1 (YB-1), also known as nuclease-sensitive element-binding protein, is a DNA- and RNA-binding protein. YB-1 is an important transcription factor with an evolutionarily ancient and conserved cold-shock domain and participates in multiple cellular processes [1]. YB-1 is encoded by the YBX1 gene and is a major component of protein complexes that mediate mRNA binding and transport [2]. In response to genotoxic stress, YB-1 translocates from the cytoplasm to the nucleus [3] where it acts as a transcriptional regulator to overcome DNA damage-dependent cell-cycle arrest and promote cell survival [2]. Moreover, YB-1 is a major component of messenger ribonucleoprotein particles in mammalian cells and regulates the stabilisation of mRNA and translation of mediators, such as profibrotic cytokine transforming growth factor (TGF)- $\beta$ and pro-inflammatory cytokine C-C motif chemokine ligand 2 (CCL2)/monocyte chemoattractant protein 1 (MCP-1) [4, 5]. YB-1 has a prominent and distinct role in the regulation of the inflammation process [6]. YB-1 seems to fulfil a pacemaker role in diverse diseases, functioning in both inflammatory/ pro-fibrogenic and tumourigenic pathways [7]. A more detailed description of YB-1 protein

Weiping Tu

and Xiangdong Fang

KARGER
Department of Nephrology, The Second Affiliated Hospital of Nanchang University,

Nanchang of Jiangxi, No. 1, Minde Road, Nanchang (People's Republic of China)

E-Mail tuweiping6102@sina.com, xiangdongfang818@sina.com 


\section{Cellular Physiology Cell Physiol Biochem 2018;46:314-321

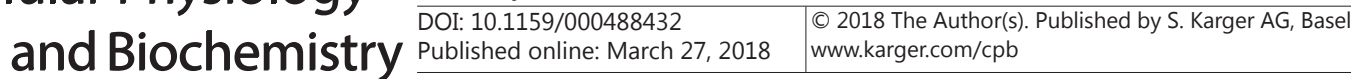

Ke et al.: Y-Box-Binding Protein 1 and Kidney Injury

structure and function can be found in two outstanding reviews by Eliseeva et al. [2] and Lyabin et al. [1].

YB-1 acts as a central regulator of gene transcription and translation of several fibrosis-related genes $[8,9]$. Recently, increasing evidence has shown that YB-1 plays a protective role in acute or chronic kidney injury $[6,10]$. Furthermore, YB-1 may be involved in the pathogenesis of obesity-related kidney disease (ORKD) [11]. Unfortunately, no comprehensive review of the role of YB-1 in kidney injury is currently available. Here, we summarise recent progress in our understanding of the function of YB- 1 in kidney injury and provide an overview of the dual role of YB-1 in kidney disease. Moreover, we propose that YB-1 is a potential therapeutic target for the treatment of kidney disease.

\section{YB-1 and AKI}

Acute kidney injury (AKI) is a common clinical syndrome that complicates up to $20 \%$ of hospital admissions and 30-50\% of intensive care unit admissions [12,13]. AKI is associated with up to an eight-fold increased risk in mortality due to limited therapy options $[14,15]$. Ischaemia-reperfusion injury (IRI), the leading cause of AKI, accounts for $50 \%$ of all cases. The pathophysiology of AKI is complex and involves multiple processes, including inflammation, autophagy, cell-cycle progression, and coagulation activation [16-18]. Recent evidence has suggested that a single insult to the kidney significantly enhances the propensity to develop chronic kidney disease (CKD) [16]. Therefore, the development of effective therapies against AKI is urgently needed.

YB-1 plays an important role not only in the onset but also in the resolution of inflammation in AKI. Generally, YB-1 regulates the expression of pro-inflammatory mediators during the acute phase of inflammation [19]. At the onset of inflammation, YB-1 upregulates the expression of pro-inflammatory factors such as interleukin (IL)-6 [20] and C-C motif chemokine ligand 5 (CCL5) [19, 21]. CCL5, an important inducer of immune cell infiltration, is transcriptionally and translationally regulated by YB-1 in monocytes/macrophages [22] and human arterial smooth muscle cells [23]. Interestingly, half-maximal YB-1 expression results in the amelioration of AKI by inhibiting CCL5 gene expression [19]. Moreover, increased tubular cell CCL5 expression was found in conditional Ybx1 knockout animals with specific depletion in monocytes/macrophages (YB-1 ${ }^{\Delta L y s M}$ ) [6]. Regulatory T cell-derived IL10 plays an important renoprotective role in murine models of ischaemia-reperfusion (I/R) [24]. However, Wang et al. [10] found that mice with half-maximal expression of YB-1 (Yb1 ${ }^{+/-}$ ) exhibited an ameliorated inflammatory response and kidney damage at the earlier stages (days 1 and 5) of I/R with aggravated kidney injury, inflammation, and less regeneration at later stages (day 21). Moreover, YB-1 was phosphorylated at serine 102 localised to the fourth intron, the IL10 gene locus, which was paralleled by enhanced IL-10 mRNA expression in mice following lipopolysaccharide (LPS) challenge and I/R. Furthermore, half-maximal expression of YB-1 led to diminished IL-10 expression upon LPS challenge, consistent with the results of a previous study [6]. However, higher YB-1 expression enhanced IL-10 mRNA expression [10]. Therefore, YB-1 exhibits both pro- and anti-inflammatory properties via IL10 gene regulation.

YB-1 alleviates AKI by mediating thrombomodulin (TM)-dependent activated protein $\mathrm{C}(\mathrm{aPC})$ signalling. Tissue factor-dependent coagulation and thrombin activation aggravate tubular injury through protease-activated receptor-1 (PAR-1)-dependent signalling [18]. Unlike thrombin, the anticoagulant serine protease aPC is nephroprotective and ameliorates acute renal injury $[25,26]$. The therapeutic application of recombinant soluble TM ameliorated IRI in rats by aPC $[27,28]$. Notably, YB-1 was required for the nephro- and cytoprotective effects of aPC in vivo and in vitro because aPC failed to provide renal protection in $\mathrm{YB}-1^{+/}$ IRI mice [29]. Furthermore, the reduction in mature YB-1 and K48-linked ubiquitination of YB-1 was prevented by aPC after renal IRI, and aPC preserved the interaction of YB-1 with the deubiquitinating enzyme otubain-1 and maintained expression of otubain-1, which was

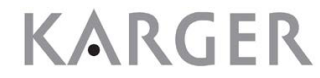


Ke et al.: Y-Box-Binding Protein 1 and Kidney Injury

required to reduce $\mathrm{K} 48$ linked YB-1 ubiquitination and stabilise YB-1 after renal IRI (Fig. 1) [29]. Given that aPC plays a key role in attenuating inflammation [30], inflammatory factors such as CCL5, IL-6 and IL10 should have been used as indicators in this study to clarify the relationship between YB-1 and inflammation.

\section{YB-1 and CKD}

CKD is defined as decreased kidney function demonstrated by a glomerular filtration rate (GFR)

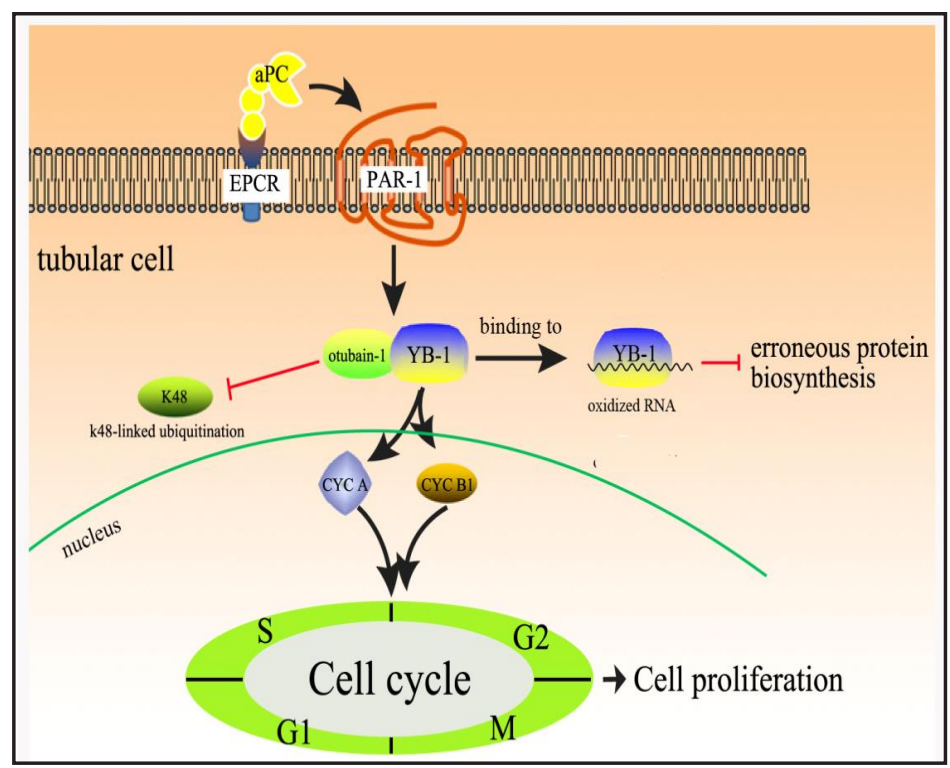

Fig. 1. Schematic presentation of the signalling pathways by which aPC regulates YB-1 expression and stability in tubular cells.

less than $60 \mathrm{~mL} / \mathrm{min}$ per $1.73 \mathrm{~m}^{2}$, markers of kidney damage, or both for at least 3 months regardless of the underlying cause. CKD is endangering the global health system. According to World Health Organization (WHO) global health estimates, 864, 226 deaths were attributed to this condition in 2012 alone [31]. CKD is currently ranked fourteenth in the list of leading causes of death, accounting for 12.2 deaths per 100,000 people [31]. The final common pathological manifestation of CKD is renal fibrosis in which multiple serum cytokines are involved. Given the role of renal fibrosis, Lindquist J et al. proposed the novel idea that the risk for organ fibrosis should be quantifiable, similar to autoimmune disorders (autoantibody titres) or cancers (tumour markers), and that treatment options may be adjustable [32], which may decrease the mortality of CKD.

YB-1 alleviates renal fibrosis through multiple pathways. Excessive cellular infiltration and prolonged inflammatory responses may aggravate tissue damage and may therefore detrimentally impact kidney function [33]. YB-1 regulates proliferation, matrix protein synthesis, chemotaxis, and phenotypic alterations in monocytic cells; it is also crucially involved in the orchestration of inflammatory responses [1]. Bernhardt et al. [6] revealed increased inflammatory cell infiltration and tubular cell CCL5 expression in YB-1 ${ }^{\Delta \mathrm{LysM}}$ mice following tubulointerstitial injury by unilateral ureteral obstruction. Furthermore, YB-1 ${ }^{\Delta \mathrm{LysM}}$ mice exhibited enhanced tissue damage, myofibroblast activation, and fibrosis. Among bone marrow-derived macrophages, YB-1 deficient macrophages had defects in cell polarisation and function, including reduced proliferation and nitric oxide production, loss of phagocytic activity, and failure to upregulate IL-10 and CCL5 expression in response to inflammatory stimuli. Co-culture with primary tubular cells confirmed these findings. These findings indicate that YB-1 has prominent and distinct roles in the resolution of inflammatory processes [6]. Moreover, YB-1 acts as a cell type-specific activator of matrix metalloproteinase (MMP)2 gene expression [34]. MMP-2 belongs to the family of zinc-dependent endopeptidases that control collagen degradation in the kidney and participate in fibrotic processes [34]. In addition, YB-1 serves as a potent negative transcriptional regulator of both the $\alpha$-smooth muscle actin and collagen type 1 alpha 1 (Col1A1) genes, which are hallmarks of mesangial activation during fibrogenesis $[35,36]$. Collectively, these results suggest that YB-1 plays a powerful role in inhibiting renal fibrosis by reducing inflammatory cell infiltration, enhancing the resolution of kidney inflammation and suppressing fibrotic genes and signalling. 
However, YB-1 shows profibrotic effects through the regulation of Col1A1 translation and enhancement of inflammation $[8,19]$. The immunosuppressive calcineurin inhibitor (CNI) cyclosporine A (CsA) can cause tubulointerstitial as well as mesangial fibrosis, with TGF- $\beta$ believed to be a central inductor [37]. Hanssen et al. [8] found that intracellular levels of YB-1 increased severalfold in mesangial cells (MCs) following CNI treatment in vitro and in vivo in mice. CsA-induced YB-1 accumulation resulted in collagen mRNA stabilisation and the subsequent generation of collagen; this result conflicts with the role of YB-1 as a negative regulator of Col1A1 gene transcription [35].

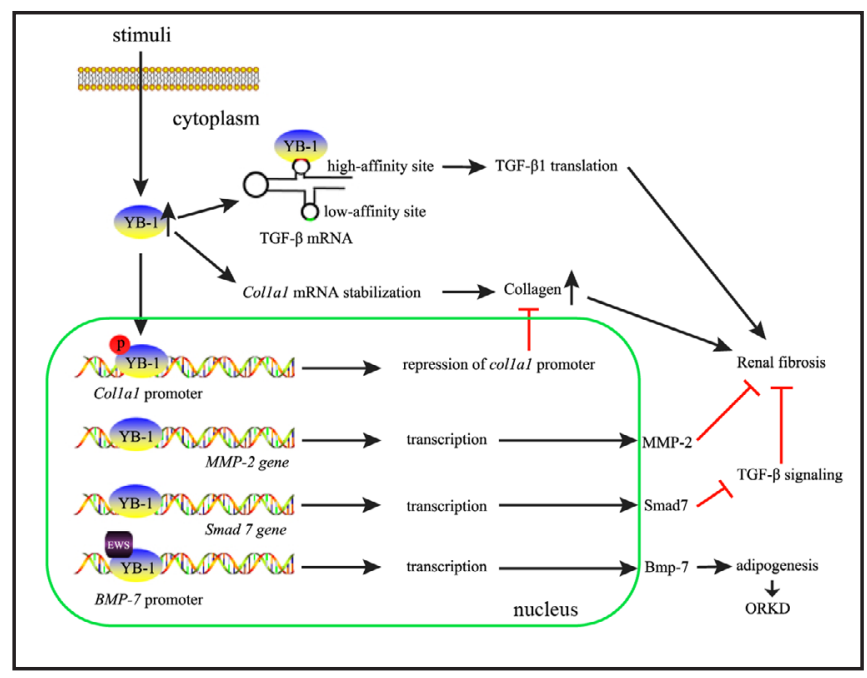

Fig. 2. Schematic presentation of the signalling pathways by which YB-1 regulates the expression of TGF- $\beta$, collagen, MMP-2 and Bmp-7 and contributes to renal fibrosis and adipogenesis, leading to ORKD.

Moreover, YB-1 can exacerbate

bacterial and sterile inflammation to promote renal fibrosis [19]. In proximal tubular cells, YB-1 controls TGF- $\beta 1$ expression by binding to a high-affinity site of TGF- $\beta 1$ mRNA to active the translation of TGF- $\beta 1$, which is an important mediator of the pathogenesis of numerous fibrotic diseases [9] (Fig. 2). Furthermore, extracellular YB-1 promotes mesangioproliferative diseases through the activation of the Notch 3 receptor, which plays an active role in the pathogenesis of glomerular diseases $[38,39]$; however, extracellular targeting of YB-1 also induces glomerular Notch-3 receptor expression and Notch signalling [40].

The phosphorylation and subcellular localisation of YB-1 may determine its effects on renal fibrosis [41] (Fig. 2). When localised to the nucleus, YB-1 acts as an anti-fibrotic protein via the repression of pro-fibrotic factors such as Col1A1 and $\alpha$-smooth muscle actin [36]. YB-1 also activates anti-fibrotic factors such as MMP-2 and Smad 7, which interferes with TGF- $\beta$ signalling and acts as an endogenous antagonist that restricts the fibrotic response $[42,43]$. In line with this finding, a recent study reported that YB-1 localised to the cytoplasm could directly stabilise Col1a1 mRNA, thus promoting fibrosis during ureteral obstruction. Conversely, the therapeutic forced nuclear compartmentalisation of phosphorylated YB-1 by small molecule $\mathrm{HSc} 025$ mediated the repression of the Col1a1 promoter and attenuated fibrosis following ureteral obstruction. Moreover, HSc025 reduced tubulointerstitial damage even when applied at later time points during maximum renal damage [41]. Therefore, induced nuclear YB-1 shuttling may be a novel anti-fibrotic treatment strategy in renal diseases.

YB-1 may contribute to renal fibrosis via the induction of epithelial-to-mesenchymal transition (EMT). Although controversial, emerging evidence indicates that renal tubular EMT is an important event in the pathophysiology of renal fibrosis [44]. A number of studies have reported that YB-1 induces EMT in cancer $[45,46]$. The mechanism by which YB-1 mediates EMT is probably related to YB-1-induced transcription and translation of vimentin and snail [46]. Vimentin is an intermediate filament protein and marker for myofibroblasts [47]. The expression of vimentin and snail correlated well with renal fibrosis [48]. This finding may explain how YB-1 regulates renal fibrosis.

YB-1 may contribute to ORKD by promoting adipogenesis. ORKD is essentially single-nephron hyperfiltration caused by a reduced ratio of nephrons to body mass. This disease is recognised as a distinct entity characterised by glomerulomegaly, progressive glomerulosclerosis and renal functional decline [49-51]. Bone morphogenic protein 7 
Ke et al.: Y-Box-Binding Protein 1 and Kidney Injury

(BMP7) is critical for mesenchymal progenitor cells to commit to the brown fat lineage [52]. YB-1 binds and activates the BMP7 promoter to promote its transcription. Moreover, YB-1 is essential for Bmp7 expression during brown adipocyte differentiation in vitro. Furthermore, Ewing Sarcoma (EWS), a multifunctional protein that is essential in determining brown fat lineage during development, forms a complex with YB-1, and this complex directly activates Bmp7 transcription to induce brown adipogenesis [11] (Fig. 2). Additionally, YB-1 showed the strongest induction (130-fold) in the white adipose tissue of cafeteria-diet fed animals [53]. YB-1 induces protein-tyrosine phosphatase 1B (PTP1B) expression by binding directly to its promoter, and the inactivation of PTP1B is related to obesity resistance [54].

\section{Conclusion and Perspective}

YB-1 plays a complicated and distinct role in acute and chronic kidney damage. During AKI, YB-1 plays a role in both the early and late phases, although the precise function of YB-1 in the different stages of AKI remains controversial. For example, YB-1 plays a renoprotective role in AKI as a downstream effector of aPC. This role may provide a novel strategy to mitigate AKI if a switch is developed to change the function of YB-1 in inflammation. In CKD, YB-1 has a dual role in the regulation of collagen synthesis, depending on its subcellular localisation. Moreover, YB-1 may accelerate renal fibrosis via TGF- $\beta$ signalling as an upstream regulator with the ability to induce EMT. In addition, YB-1 may play an active role in ORKD by mediating adipogenesis, which offers a new direction to alleviate ORKD. Overall, although some advancements have been made in our understanding of the complicated role of YB-1 in kidney injury, further basic and preclinical studies are needed to validate YB-1 as a potential therapeutic target to restrict kidney disease.

\section{Acknowledgements}

We thank Mr. Ben Ke for guidance regarding this article. This work was supported by grants from the National Natural Science Foundation of China (General Program 81760130).

\section{Disclosure Statement}

All authors declare that there are no conflicts of interest.

\section{References}

1 Lyabin DN, Eliseeva IA, Ovchinnikov LP: YB-1 protein: functions and regulation. Wiley Interdiscip Rev RNA 2014;5:95-110.

-2 Eliseeva IA, Kim ER, Guryanov SG, Ovchinnikov LP, Lyabin DN: Y-box-binding protein 1 (YB-1) and its functions. Biochemistry (Mosc) 2011;76:1402-1433.

-3 Gimenez-Bonafe P, Fedoruk MN, Whitmore TG, Akbari M, Ralph JL, Ettinger S, Gleave ME, Nelson CC: YB-1 is upregulated during prostate cancer tumor progression and increases P-glycoprotein activity. Prostate 2004;59:337-349.

4 Dhawan L, Liu B, Pytlak A, Kulshrestha S, Blaxall BC, Taubman MB: Y-box binding protein 1 and RNase UK114 mediate monocyte chemoattractant protein 1 mRNA stability in vascular smooth muscle cells. Mol Cell Biol 2012;32:3768-3775.

5 Jenkins RH, Bennagi R, Martin J, Phillips AO, Redman JE, Fraser DJ: A conserved stem loop motif in the 5'untranslated region regulates transforming growth factor-beta(1) translation. PLoS One 2010;5:e12283. 


\section{Cellular Physiology Cell Physiol Biochem 2018;46:314-321 \begin{tabular}{l|l} 
DOI: 10.1159/000488432 & and Biochemistry \\
Published online: March 27, 2018 & $\begin{array}{l}\text { O 2018 The Author(s). Published by S. Karger AG, Basel } \\
\text { www.karger.com/cpb }\end{array}$
\end{tabular}}

Ke et al.: Y-Box-Binding Protein 1 and Kidney Injury

6 Bernhardt A, Fehr A, Brandt S, Jerchel S, Ballhause TM, Philipsen L, Stolze S, Geffers R, Weng H, Fischer KD, Isermann B, Brunner-Weinzierl MC, Batra A, Siegmund B, Zhu C, Lindquist JA, Mertens PR: Inflammatory cell infiltration and resolution of kidney inflammation is orchestrated by the cold-shock protein Y-box binding protein-1. Kidney Int 2017;10.1016/j.kint.2017.03.035

7 Brandt S, Raffetseder U, Djudjaj S, Schreiter A, Kadereit B, Michele M, Pabst M, Zhu C, Mertens PR: Cold shock Y-box protein-1 participates in signaling circuits with auto-regulatory activities. Eur J Cell Biol 2012;91:464-471.

-8 Hanssen L, Frye BC, Ostendorf T, Alidousty C, Djudjaj S, Boor P, Rauen T, Floege J, Mertens PR, Raffetseder U: Y-box binding protein-1 mediates profibrotic effects of calcineurin inhibitors in the kidney. J Immunol 2011;187:298-308.

-9 Fraser DJ, Phillips AO, Zhang X, van Roeyen CR, Muehlenberg P, En-Nia A, Mertens PR: Y-box protein-1 controls transforming growth factor-beta1 translation in proximal tubular cells. Kidney Int 2008;73:724732.

10 Wang J, Djudjaj S, Gibbert L, Lennartz V, Breitkopf DM, Rauen T, Hermert D, Martin IV, Boor P, Braun GS, Floege J, Ostendorf T, Raffetseder U: YB-1 orchestrates onset and resolution of renal inflammation via IL10 gene regulation. J Cell Mol Med 2017;10.1111/jcmm.13260

11 Park JH, Kang HJ, Kang SI, Lee JE, Hur J, Ge K, Mueller E, Li H, Lee BC, Lee SB: A multifunctional protein, EWS, is essential for early brown fat lineage determination. Dev Cell 2013;26:393-404.

12 Chertow GM, Burdick E, Honour M, Bonventre JV, Bates DW: Acute kidney injury, mortality, length of stay, and costs in hospitalized patients. J Am Soc Nephrol 2005;16:3365-3370.

13 Star RA: Treatment of acute renal failure. Kidney Int 1998;54:1817-1831.

14 Simmons EM, Himmelfarb J, Sezer MT, Chertow GM, Mehta RL, Paganini EP, Soroko S, Freedman S, Becker K, Spratt D, Shyr Y, Ikizler TA, Group PS: Plasma cytokine levels predict mortality in patients with acute renal failure. Kidney Int 2004;65:1357-1365.

15 Elahi MM, Lim MY, Joseph RN, Dhannapuneni RR, Spyt TJ: Early hemofiltration improves survival in postcardiotomy patients with acute renal failure. Eur J Cardiothorac Surg 2004;26:1027-1031.

16 Bolisetty S, Zarjou A, Agarwal A: Heme Oxygenase 1 as a Therapeutic Target in Acute Kidney Injury. Am J Kidney Dis 2017;69:531-545.

17 Megyesi J, Andrade L, Vieira JM, Jr., Safirstein RL, Price PM: Positive effect of the induction of p21WAF1/ CIP1 on the course of ischemic acute renal failure. Kidney Int 2001;60:2164-2172.

18 Sevastos J, Kennedy SE, Davis DR, Sam M, Peake PW, Charlesworth JA, Mackman N, Erlich JH: Tissue factor deficiency and PAR-1 deficiency are protective against renal ischemia reperfusion injury. Blood 2007;109:577-583.

19 Hanssen L, Alidousty C, Djudjaj S, Frye BC, Rauen T, Boor P, Mertens PR, van Roeyen CR, Tacke F, Heymann F, Tittel AP, Koch A, Floege J, Ostendorf T, Raffetseder U: YB-1 is an early and central mediator of bacterial and sterile inflammation in vivo. J Immunol 2013;191:2604-2613.

20 Kang S, Lee TA, Ra EA, Lee E, Choi H, Lee S, Park B: Differential control of interleukin-6 mRNA levels by cellular distribution of YB-1. PLoS One 2014;9:e112754.

-21 Alidousty C, Rauen T, Hanssen L, Wang Q, Alampour-Rajabi S, Mertens PR, Bernhagen J, Floege J, Ostendorf T, Raffetseder U: Calcineurin-mediated YB-1 dephosphorylation regulates CCL5 expression during monocyte differentiation. J Biol Chem 2014;289:21401-21412.

-22 Raffetseder U, Rauen T, Djudjaj S, Kretzler M, En-Nia A, Tacke F, Zimmermann HW, Nelson PJ, Frye BC, Floege J, Stefanidis I, Weber C, Mertens PR: Differential regulation of chemokine CCL5 expression in monocytes/macrophages and renal cells by Y-box protein-1. Kidney Int 2009;75:185-196.

23 Krohn R, Raffetseder U, Bot I, Zernecke A, Shagdarsuren E, Liehn EA, van Santbrink PJ, Nelson PJ, Biessen EA, Mertens PR, Weber C: Y-box binding protein-1 controls CC chemokine ligand-5 (CCL5) expression in smooth muscle cells and contributes to neointima formation in atherosclerosis-prone mice. Circulation 2007;116:1812-1820.

24 Ostmann A, Paust HJ, Panzer U, Wegscheid C, Kapffer S, Huber S, Flavell RA, Erhardt A, Tiegs G: Regulatory T cell-derived IL-10 ameliorates crescentic GN. J Am Soc Nephrol 2013;24:930-942.

25 Gupta A, Gerlitz B, Richardson MA, Bull C, Berg DT, Syed S, Galbreath EJ, Swanson BA, Jones BE, Grinnell BW: Distinct functions of activated protein C differentially attenuate acute kidney injury. J Am Soc Nephrol 2009;20:267-277. 


\section{Cellular Physiology Cell Physiol Biochem 2018;46:314-321 \begin{tabular}{l|l} 
DOI: 10.1159/000488432 & and Biochemistry \\
Published online: March 27, 2018 & $\begin{array}{l}\text { O 2018 The Author(s). Published by S. Karger AG, Basel } \\
\text { www.karger.com/cpb }\end{array}$
\end{tabular}}

Ke et al.: Y-Box-Binding Protein 1 and Kidney Injury

26 Gupta A, Williams MD, Macias WL, Molitoris BA, Grinnell BW: Activated protein C and acute kidney injury: Selective targeting of PAR-1. Curr Drug Targets 2009;10:1212-1226.

27 Sharfuddin AA, Sandoval RM, Berg DT, McDougal GE, Campos SB, Phillips CL, Jones BE, Gupta A, Grinnell BW, Molitoris BA: Soluble thrombomodulin protects ischemic kidneys. J Am Soc Nephrol 2009;20:524-534.

28 Ozaki T, Anas C, Maruyama S, Yamamoto T, Yasuda K, Morita Y, Ito Y, Gotoh M, Yuzawa Y, Matsuo S: Intrarenal administration of recombinant human soluble thrombomodulin ameliorates ischaemic acute renal failure. Nephrol Dial Transplant 2008;23:110-119.

29 Dong W, Wang H, Shahzad K, Bock F, Al-Dabet MM, Ranjan S, Wolter J, Kohli S, Hoffmann J, Dhople VM, Zhu C, Lindquist JA, Esmon CT, Grone E, Grone HJ, Madhusudhan T, Mertens PR, Schluter D, Isermann B: Activated Protein C Ameliorates Renal Ischemia-Reperfusion Injury by Restricting Y-Box Binding Protein-1 Ubiquitination. J Am Soc Nephrol 2015;26:2789-2799.

-30 Carney EF: Inflammation: Activated protein C inhibits inflammasome activation in IRI. Nat Rev Nephrol 2017;13:662.

-31 Webster AC, Nagler EV, Morton RL, Masson P: Chronic Kidney Disease. Lancet 2017;389:1238-1252.

-32 Lindquist JA, Schneider A, Mertens PR: Regulation of endogenous brakes to kidney fibrosis: turning the view upside down. J Mol Med (Berl) 2017;95:571-573.

33 Weidenbusch M, Anders HJ: Tissue microenvironments define and get reinforced by macrophage phenotypes in homeostasis or during inflammation, repair and fibrosis. J Innate Immun 2012;4:463-477.

34 Mertens PR, Harendza S, Pollock AS, Lovett DH: Glomerular mesangial cell-specific transactivation of matrix metalloproteinase 2 transcription is mediated by YB-1. J Biol Chem 1997;272:22905-22912.

-35 Norman JT, Lindahl GE, Shakib K, En-Nia A, Yilmaz E, Mertens PR: The Y-box binding protein YB-1 suppresses collagen alpha 1 (I) gene transcription via an evolutionarily conserved regulatory element in the proximal promoter. J Biol Chem 2001;276:29880-29890.

-36 Zhang A, Liu X, Cogan JG, Fuerst MD, Polikandriotis JA, Kelm RJ Jr, Strauch AR: YB-1 coordinates vascular smooth muscle alpha-actin gene activation by transforming growth factor beta1 and thrombin during differentiation of human pulmonary myofibroblasts. Mol Biol Cell 2005;16:4931-4940.

37 Islam M, Burke JF, Jr., McGowan TA, Zhu Y, Dunn SR, McCue P, Kanalas J, Sharma K: Effect of antitransforming growth factor-beta antibodies in cyclosporine-induced renal dysfunction. Kidney Int 2001;59:498-506.

-38 Rauen T, Raffetseder U, Frye BC, Djudjaj S, Muhlenberg PJ, Eitner F, Lendahl U, Bernhagen J, Dooley S, Mertens PR: YB-1 acts as a ligand for Notch-3 receptors and modulates receptor activation. J Biol Chem 2009;284:26928-26940.

39 Niranjan T, Bielesz B, Gruenwald A, Ponda MP, Kopp JB, Thomas DB, Susztak K: The Notch pathway in podocytes plays a role in the development of glomerular disease. Nat Med 2008;14:290-298.

40 Raffetseder U, Rauen T, Boor P, Ostendorf T, Hanssen L, Floege J, En-Nia A, Djudjaj S, Frye BC, Mertens PR: Extracellular YB-1 blockade in experimental nephritis upregulates Notch-3 receptor expression and signaling. Nephron Exp Nephrol 2011;118:e100-108.

41 Wang J, Gibbert L, Djudjaj S, Alidousty C, Rauen T, Kunter U, Rembiak A, Enders D, Jankowski V, Braun GS, Floege J, Ostendorf T, Raffetseder U: Therapeutic nuclear shuttling of YB-1 reduces renal damage and fibrosis. Kidney Int 2016;90:1226-1237.

42 Dooley S, Said HM, Gressner AM, Floege J, En-Nia A, Mertens PR: Y-box protein-1 is the crucial mediator of antifibrotic interferon-gamma effects. J Biol Chem 2006;281:1784-1795.

43 Mertens PR, Alfonso-Jaume MA, Steinmann K, Lovett DH: YB-1 regulation of the human and rat gelatinase A genes via similar enhancer elements. J Am Soc Nephrol 1999;10:2480-2487.

44 Menon MC, Ross MJ: Epithelial-to-mesenchymal transition of tubular epithelial cells in renal fibrosis: a new twist on an old tale. Kidney Int 2016;89:263-266.

45 Gopal SK, Greening DW, Mathias RA, Ji H, Rai A, Chen M, Zhu HJ, Simpson RJ: YBX1/YB-1 induces partial EMT and tumourigenicity through secretion of angiogenic factors into the extracellular microenvironment. Oncotarget 2015;6:13718-13730.

46 Khan MI, Adhami VM, Lall RK, Sechi M, Joshi DC, Haidar OM, Syed DN, Siddiqui IA, Chiu SY, Mukhtar H: YB-1 expression promotes epithelial-to-mesenchymal transition in prostate cancer that is inhibited by a small molecule fisetin. Oncotarget 2014;5:2462-2474. 


\section{Cellular Physiology Cell Physiol Biochem 2018:46:314-321

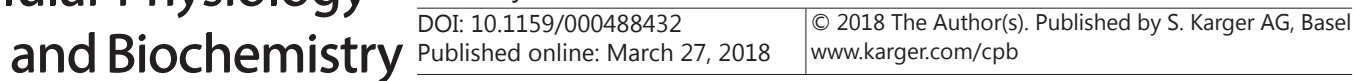

Ke et al.: Y-Box-Binding Protein 1 and Kidney Injury

47 Kaissling B, Le Hir M: The renal cortical interstitium: morphological and functional aspects. Histochem Cell Biol 2008;130:247-262.

48 Ohnuki K, Umezono T, Abe M, Kobayashi T, Kato M, Miyauchi M, Yamamoto N, Kimura M, Toyoda M, Suzuki D: Expression of transcription factor Snai1 and tubulointerstitial fibrosis in progressive nephropathy. J Nephrol 2012;25:233-239.

49 Yamamoto T, Takabatake Y, Takahashi A, Kimura T, Namba T, Matsuda J, Minami S, Kaimori JY, Matsui I, Matsusaka T, Niimura F, Yanagita M, Isaka Y: High-Fat Diet-Induced Lysosomal Dysfunction and Impaired Autophagic Flux Contribute to Lipotoxicity in the Kidney. J Am Soc Nephrol 2017;28:1534-1551.

50 D'Agati VD, Chagnac A, de Vries AP, Levi M, Porrini E, Herman-Edelstein M, Praga M: Obesity-related glomerulopathy: clinical and pathologic characteristics and pathogenesis. Nat Rev Nephrol 2016;12:453471.

51 Unger RH, Clark GO, Scherer PE, Orci L: Lipid homeostasis, lipotoxicity and the metabolic syndrome. Biochim Biophys Acta 2010;1801:209-214.

-52 Tseng YH, Kokkotou E, Schulz TJ, Huang TL, Winnay JN, Taniguchi CM, Tran TT, Suzuki R, Espinoza DO, Yamamoto Y, Ahrens MJ, Dudley AT, Norris AW, Kulkarni RN, Kahn CR: New role of bone morphogenetic protein 7 in brown adipogenesis and energy expenditure. Nature 2008;454:1000-1004.

53 Lopez IP, Milagro FI, Marti A, Moreno-Aliaga MJ, Martinez JA, De Miguel C: Gene expression changes in rat white adipose tissue after a high-fat diet determined by differential display. Biochem Biophys Res Commun 2004;318:234-239.

54 Fukada T, Tonks NK: Identification of YB-1 as a regulator of PTP1B expression: implications for regulation of insulin and cytokine signaling. EMBO J 2003;22:479-493. 